\title{
Report by A. BERSON about the aerological expedition of the Royal Aeronautic Observatory to East Africa in 1908
}

\section{R. SÜRING}

\author{
Translated from German and edited by ESTHER VOLKEN ${ }^{1}$ STEFAN BRÖNNIMANN ${ }^{2,3, *}$ \\ ${ }^{1}$ Proclim, Bern, Switzerland \\ ${ }^{2}$ Oeschger Centre for Climate Change Research, University of Bern, Switzerland \\ ${ }^{3}$ Institute of Geography, University of Bern, Switzerland
}

Original citation:

SÜRING, R., 1910: A. Berson's Bericht über die aerologische Expedition des königlichen aeronautischen Observatoriums nach Ostafrika im Jahre 1908. - Meteorol. Z. 27, 536-542.

\section{Suggested citation:}

SÜRING, R., 1910: A. Berson's Bericht über die aerologische Expedition des königlichen aeronautischen Observatoriums nach Ostafrika im Jahre 1908 (Report by A. BERSON about the aerological expedition of the Royal Aeronautic Observatory to East Africa in 1908). - Meteorol. Z. 27, 536-542 (translated and edited by VOLKEN, E. and S. BRÖNNIMANN - Meteorol. Z. 22 (2013), 343-348)

\begin{abstract}
This paper is the edited translation of the paper "A. Berson's Bericht über die aerologische Expedition des königlichen aeronautischen Observatoriums nach Ostafrika im Jahre 1908" (Report by A. BERSON about the aerological expedition of the Royal Aeronautic Observatory to East Africa in 1908) that was published 1910 in the Meteorologische Zeitschrift 27, 536-542. The paper, provided by R. SÜRING, co-editor of the journal, is a summary of a more extensive report published in the same year. ${ }^{1}$
\end{abstract}

Keywords: Historical aerology, Berson expedition, East African monsoon, Lake Victoria.

Superscript numbers indicate original footnotes (translated at the bottom of the page), E... numbers indicate editorial endnotes (at the end of the article), square brackets [] indicate editorial comments in the text.

Plans for an aerological study of the atmosphere over the oceans and the tropical regions had been pursued by BERSON $^{\mathrm{E} 2}$ since 1901 . With considerable private support ${ }^{\mathrm{E} 3}$, they could partly be realized in 1908 by an expedition equipped by the Director of the Prussian Aeronautic Observatory, Councillor [Geheimrat] Dr. ASSMANN ${ }^{\mathrm{E} 4}$.

The expedition in which Prof. BERSON and Dr ELIAS $^{\mathrm{E} 5}$ participated as scientific staff primarily served to carry out monsoon studies. For the eastern monsoon regions ${ }^{\mathrm{E} 6}$, the Indian Meteorological Office ${ }^{\mathrm{E} 7}$ and the German geodetic vessel "Planet" ${ }^{\text {" }}$ had carried out some sparse experiments. It therefore seemed promising to start the work at the western coast of the Indian Ocean, at the coasts and in the interior of East Africa, that is the start-

\footnotetext{
"Corresponding author: Stefan Brönnimann, Oeschger Centre for Climate Change Research and Institute of Geography, University of Bern, Hallerstrasse 12, 3012 Bern, Switzerland,

e-mail: stefan.broennimann@giub.unibe.ch

${ }^{1}$ Bericht über die aerologische Expedition des Königlichen Aeronautischen Observatoriums nach Ostafrika im Jahre 1908. [Results of the works carried out by the Royal Prussian Aeronautical Observatory at Lindenberg. Braunschweig], Friedr. Vieweg and Son, 1910. 4.7, XXXIII, 119 p., 21 Tables. ${ }^{\mathrm{E}}$
}

ing and ending point of the SW and NE monsoon, respectively. Lake Victoria ${ }^{\mathrm{E} 6}$ with an area of $70^{\prime} 000 \mathrm{~km}^{2}$ is relatively easily accessible and therefore seemed particularly adequate for aerological studies, because using a steamboat considerably facilitates the work with kites and registering balloons. However, these natural advantages of a lake could only be used to a limited extent, since, as a result of adverse coincidences, there was only one ship available, moving no faster than 6.5 nautical miles per hour. Unfortunately, the rubber balloons brought along turned out to be of minor quality, so that during the work phase between end of July and beginning of October, only 26 registering balloons and 17 kite ascents yielded useful results. In addition, 53 pilot balloon ascents were carried out. The exact identification of their flight route was particularly important with regard to the purpose of this study. By the end of September, a part of the expedition moved to Mombasa ${ }^{\mathrm{E} 6}$ at the East African coast, so that some of the ascents could be carried out simultaneously in the interior and at the coast. By the beginning of December, kites and pilot balloons were started in larger numbers (and, in addition, two registering balloons) at the coast (Dar es Salaam ${ }^{\mathrm{E} 6}$ ), in the waters near Zanzibar ${ }^{\mathrm{E} 6}$ and in the Mozambique Channel ${ }^{\mathrm{E} 6}$. 
Accordingly, with regard to the monsoon studies of the expedition, four phases can be distinguished:

1. Observations of the monsoon (or rather of the SE trade wind) on Lake Victoria and at the eastern coast of the lake (Shirati $\left.{ }^{\mathrm{E} 6}\right)$ between end of July and beginning of October.

2. End of the SW monsoon in Mombasa between end of September and beginning of October.

3. Transitional period to NE winds, observed in Dar es Salaam, in the coastal waters at Zanzibar and in the Mozambique Channel between mid-October and mid-November.

4. Typical NE monsoon in Dar es Salaam and in the coastal waters between mid-November and beginning of December.

On Lake Victoria, there is no SW monsoon during the dry period. The predominant wind direction, apart from daily interruptions, is rather SE, i.e., the trade wind from the South Indian Ocean. The trade wind, however, often turns to south or even southwest. It seems that this monsoon-like cycle is related to the southward shift of the heat centre in the interior of Africa. The area of this diurnally modulated, monsoon-like trade wind has an upper limit at 3000 to $4000 \mathrm{~m}$ a.s.l. (about $2500 \mathrm{~m}$ above the lake), where it is replaced by an anti monsoon (anti-trade wind) with a northerly component. The seasonallymodulated antimonsoon rotates opposite to the lower wind direction and reaches up to about $6000 \mathrm{~m}$ a.s.l. Further details about these wind flows will become substantially clearer by taking into consideration the temperature conditions. This is why the latter will be discussed first.

Over Lake Victoria, the mean values are as follows [Table 1].

The mean temperature decrease up to $13 \mathrm{~km}$ altitude $\left.\left(0.67{ }^{\circ} \mathrm{C} / / 100 \mathrm{~m}\right]\right)$ is more pronounced than in the temperate zones. The almost continuous decrease is much more rarely disrupted by inversions or isothermal conditions and, at the equator, results in temperatures that are unknown in temperate latitudes. The temperature of $-84.3{ }^{\circ} \mathrm{C}$ measured at $19300 \mathrm{~m}$ is probably the lowest air temperature ever registered in the atmosphere.

Temperature and wind are distinctly stratified. The temperature gradient shows maxima at 3000 and $11000 \mathrm{~m}$ [a.s.1.] and minima at 6000 and above $17000 \mathrm{~m}$. At $3000 \mathrm{~m}$, the wind calms down considerably and relative humidity increases up to that level (the mean altitude of maximum humidity is between 3600 and $3700 \mathrm{~m}$ ). The upper limit of the monsoon-like trade wind and also of the daily wind pattern therefore clearly appears in the mean values. The same is true for the overlying zone with a purely seasonal wind pattern, i.e., the antimonsoon from NE to NW. Up to its upper limit at 6000 to $6500 \mathrm{~m}$ the temperature gradient decreases considerably, relative humidity often shows again a slow decrease and wind speed, which at first increases, has a second maximum at $6000 \mathrm{~m}$. Since the antimonsoon
[Table 1: Mean values of temperature (in ${ }^{\circ} \mathrm{C}$ ), lapse rate (in ${ }^{\circ} \mathrm{C} / 100 \mathrm{~m}$ ), and wind speed as a function of altitude ( $\mathrm{m}$ a.s.l) for the ascents performed at Lake Victoria. $]^{\mathrm{E} 9}$

\begin{tabular}{|c|c|c|c|}
\hline Altitude a.s.l. & Temperature & $\begin{array}{c}\text { Temperature } \\
\text { decrease per } 100 \mathrm{~m}\end{array}$ & $\begin{array}{l}\text { wind } \\
(\mathrm{m} / \mathrm{s})\end{array}$ \\
\hline \multirow[t]{2}{*}{1140} & $(23.2)$ & & 3.1 \\
\hline & & 1.06 & \\
\hline \multirow[t]{2}{*}{1500} & 19.4 & & 4.6 \\
\hline & & 0.62 & \\
\hline \multirow[t]{2}{*}{2000} & 15.4 & & 4.5 \\
\hline & & 0.73 & \\
\hline \multirow[t]{2}{*}{2500} & 11.6 & & 3.6 \\
\hline & & 0.74 & \\
\hline \multirow[t]{2}{*}{3000} & 7.8 & & 3.1 \\
\hline & & 0.62 & \\
\hline \multirow[t]{2}{*}{4000} & 1.7 & & 4.4 \\
\hline & & 0.54 & \\
\hline \multirow[t]{2}{*}{5000} & -3.8 & & 6.0 \\
\hline & & 0.53 & \\
\hline \multirow[t]{2}{*}{6000} & -9.6 & & 4.5 \\
\hline & & 0.62 & \\
\hline \multirow[t]{2}{*}{7000} & -15.0 & & 5.8 \\
\hline & & 0.70 & \\
\hline \multirow[t]{2}{*}{8000} & -22.3 & & 6.0 \\
\hline & & 0.70 & \\
\hline \multirow[t]{2}{*}{9000} & -26.9 & & 5.2 \\
\hline & & 0.72 & \\
\hline \multirow[t]{2}{*}{10000} & -34.1 & & 7.2 \\
\hline & & 0.75 & \\
\hline \multirow[t]{2}{*}{11000} & -41.6 & & 8.6 \\
\hline & & 0.70 & \\
\hline \multirow[t]{2}{*}{12000} & -50.4 & & 6.5 \\
\hline & & 0.66 & \\
\hline \multirow[t]{2}{*}{13000} & -57.0 & & 8.9 \\
\hline & & 0.52 & \\
\hline \multirow[t]{2}{*}{14000} & -62.2 & & 9.3 \\
\hline & & 0.47 & \\
\hline \multirow[t]{2}{*}{15000} & -66.2 & & 7.8 \\
\hline & & 0.41 & \\
\hline \multirow[t]{2}{*}{16000} & -70.4 & & 10.7 \\
\hline & & 0.35 & \\
\hline \multirow[t]{2}{*}{17000} & -75.9 & & 13.6 \\
\hline & & $(0.16)$ & \\
\hline \multirow[t]{2}{*}{18000} & -82.5 & & 14.9 \\
\hline & & $(0.14)$ & \\
\hline \multirow[t]{2}{*}{19000} & -83.9 & & \\
\hline & & $(0.12)$ & \\
\hline 19300 & -84.3 & & \\
\hline
\end{tabular}

blows from hotter into cooler land areas, there is sometimes cloud formation with weak rainfall. Above $6000 \mathrm{~m}$, the temperature gradient increases to an absolute maximum of $0.75{ }^{\circ} \mathrm{C}[/ 100 \mathrm{~m}]$ between 10 and $11 \mathrm{~km}$, relative humidity decreases to 20 to 30 per cent, the wind increases in strength except for some disturbances and comes predominantly from eastern directions. The flow is often meandering [Schleifenbildungen der Luftströmung sind häufig]. From time to time, there is even air movement from the west inbetween or above this layer. Temperature variability increases considerably with height. At an alti- 
[Table 2: Temperature difference between the interior and the coast. $]^{\mathrm{E} 11}$

\begin{tabular}{cccccc}
\hline 1000 & 1500 & 2000 & 2500 & 3000 & m a.s.1. \\
\hline 3.2 & 2.2 & 1 & 0.7 & -0.6 & ${ }^{\circ} \mathrm{C}$ \\
\hline
\end{tabular}

tude of $1500 \mathrm{~m}$, i.e, just a few hundred meters above the lake, temperature maxima and minima (out of 26 ascents) span a range of only $7.5^{\circ} \mathrm{C}$. However, at $8000 \mathrm{~m}$ (out of 5 ascents) the range is $14^{\circ} \mathrm{C}$.

The identification of an "upper inversion" $\mathrm{E} 10$ at a height between 15 to $17 \mathrm{~km}$ is particularly important. However, it took on a quite different form than usually, in that an upper isothermal layer usually occurred either after a gradual weakening of the vertical temperature gradient, or initiated by a sudden inversion, above which a large temperature gradient was found, which then turned into a slow temperature change.

A comparison of the vertical temperature distribution between Lake Victoria and the coast could only be carried out for heights up to $3000 \mathrm{~m}$, because at the coast, only kite ascents were carried out. With the exception of the bottommost layers, where as a result of the specific ascent location near a beach, an enormous temperature gradient was sometimes observed $\left(7\right.$ to $8{ }^{\circ} \mathrm{C}$ within the first $50 \mathrm{~m}$ ), the vertical temperature decrease is considerably slower at the coast than further inland. As a consequence, already at a height of $3000 \mathrm{~m}$, it is warmer over the coast than over the interior. Towards the end of the SW monsoon the difference 'interior minus coast' was: as follows [Table 2].

From this data we can conclude that the air pressure gradient decreases with increasing height towards the interior, reverses further up for some kilometres of altitude, and then again is directed from ESE to WNW because of the sharp temperature gradient in the interior. Under these assumptions, the changes of wind direction and velocity over Lake Victoria could be explained easily.

The kite ascents at the coast show quite clearly the differences between conditions with SW monsoon and conditions with NE monsoon. During both periods, there is an adiabatic or super-adiabatic temperature decrease in the bottommost layers. During SW monsoon, after a decrease of the gradient to half of its amount, there is again a considerable increase above $1500 \mathrm{~m}$ (gradient: $0.64{ }^{\circ} \mathrm{C}$ ). During NE monsoon, on the other hand, the temperature gradient remains small above $500 \mathrm{~m}$ and decreases to $0.37{ }^{\circ} \mathrm{C}$ per $100 \mathrm{~m}$ at $2500 \mathrm{~m}$. The graphs of the wind speed [Fig. 1] show a directly opposite behaviour. For SW wind, wind speed continuously increases from $4 \mathrm{~m} / \mathrm{s}$ to $10 \mathrm{~m} / \mathrm{s}$ at $2000 \mathrm{~m}$, whereas the $\mathrm{NE}$ wind increases in the bottommost layers from 5 to $6.5 \mathrm{~m} / \mathrm{s}$, but then continuously calms down $(2.8 \mathrm{~m} / \mathrm{s}$ at $2000 \mathrm{~m}$ ). The following graph [Fig. 1], taken from the report, clearly shows the differences.

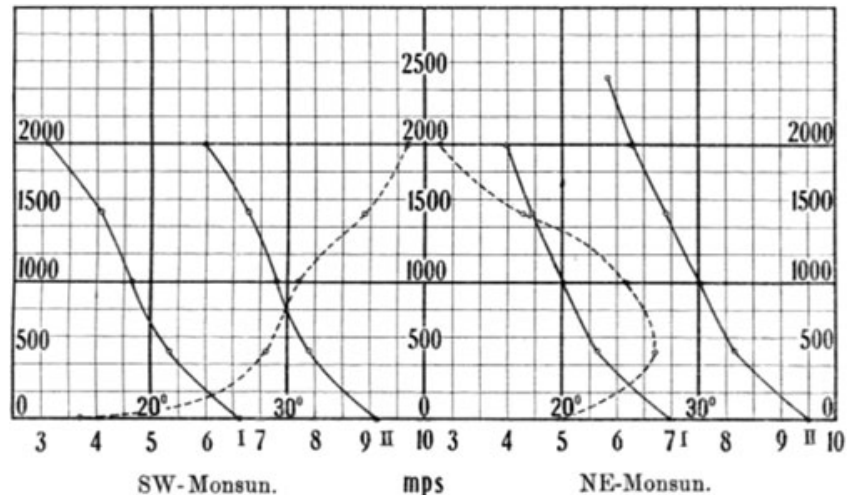

Figure 1: Vertical profile of temperature [solid, ${ }^{\circ} \mathrm{C}$ ] and wind speed [dashed, m/s] during SW monsoon [left] and NE monsoon [right]. [The profiles are from kite ascents at the coast. Curves I are derived from mean values, curves II from the vertical gradients. Curves II are shifted to the right by $10{ }^{\circ} \mathrm{C}$ for display purposes.]

The curves labelled "I" were formed from mean values, curves "II" were derived from the vertical gradient. The starting point of curves "II" is offset by $10^{\circ}[\mathrm{C}]$ to the right for reasons of clarity. The temperature values for the SW monsoon agree well with the numbers found by FIELD (Met. Zeitschr. 1909, p. 417) ${ }^{\mathrm{E} 7}$ over the Gulf of Bengal $^{\mathrm{E} 6}$ and also with the numbers found by VAN BEMMELEN and BRAAK in Batavia ${ }^{\mathrm{E} 6} .{ }^{2}$ During the transition period with SE trade wind, there is about the same temperature distribution as for SW monsoon. This means that the sudden isothermal conditions, complete dryness and calm in the layer below $1000 \mathrm{~m}$, as was found by trade wind expeditions for the SE trade wind, are missing. The increasing temperature gradient above $1000 \mathrm{~m}$ for SW monsoon indicates that the pressure gradients directed from the eastern coast of Africa towards India weaken with height, so that the SW monsoon disappears at some $1000 \mathrm{~m}$ height. On the other hand, the small temperature gradient in the NE wind causes the pressure areas over Africa to drift apart so that the wind disappears at a very low altitude.

During times of SE trade wind in Dar es Salaam, ascents were carried out in the Mozambique Channel. During those ascents, the trade wind was deflected to the left towards NE [northeasterlies] in the lower layers. Higher up, the wind was very irregular. However, it seems that there was E to SE trade wind at medium elevations with a small temperature gradient in the beginning, which then became stronger and turned into an anti-trade wind with a very small temperature gradient at $10 \mathrm{~km}$ height. The high temperature up to about $3000 \mathrm{~m}$ is noteworthy, leading to a gradient towards north at a very low altitude. Thus, the following values were measured:

${ }^{2}$ Preliminary report upon the investigation of the upper air-layers begun at Batavia in 1909. Verh. K. Akad. Van Wetensch. te Amsterdam, 1910. ${ }^{\text {E12 }}$ 
[Table 3: Temperature (in ${ }^{\circ} \mathrm{C}$ ) in the lowest $3000 \mathrm{~m}$ of the atmosphere at $21^{\circ}-24^{\circ} \mathrm{S}$ and at equatorial coastal zones.] ${ }^{\mathrm{E} 13}$

\begin{tabular}{lcccccccc}
\hline \multicolumn{1}{c}{ Location } & Time & 0 & 500 & 1000 & 1500 & 2000 & 2500 & $3000 \mathrm{~m}$ \\
\hline $21-24^{\circ} \mathrm{S}$ latitude & 26 to 30 Oct. & 26.4 & 24.9 & 24.6 & 22.1 & 18.5 & 15.3 & $11.4^{\circ}$ \\
Equatorial coastal zones & 30 Oct. to 1 Nov. & 27.0 & 22.3 & 18.3 & 15.5 & 13.8 & 10.7 & $8.4^{\circ}$ \\
\hline
\end{tabular}

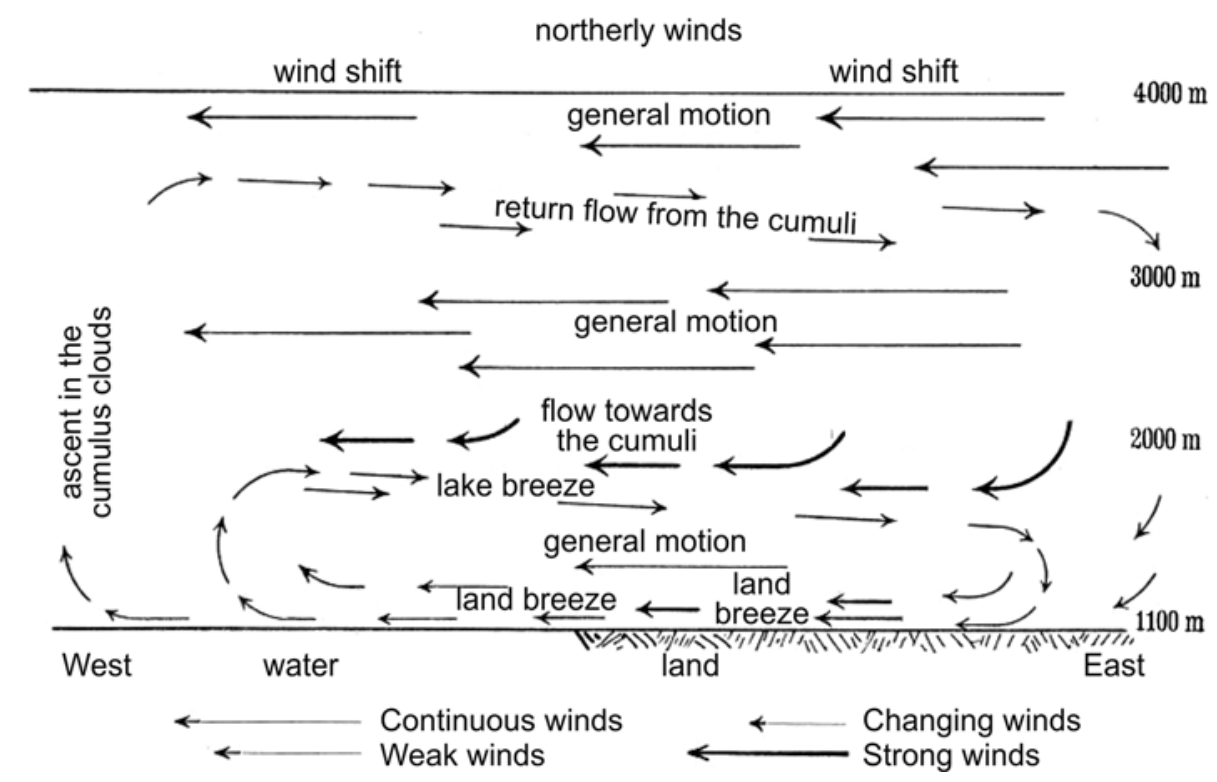

Figure 2: Schematic representation of the winds on the eastern shore of Lake Victoria ${ }^{\mathrm{E} 6}$ during early morning hours.

While the temperature at Zanzibar ${ }^{\mathrm{E} 6}$ was still $0.5^{\circ}[\mathrm{C}]$ above the temperature at the Tropic of Capricorn, the temperature at the latter was not less than $6.5^{\circ}$ above the former at an elevation of 1000 to $1500 \mathrm{~m}$. Further up, the difference decreased slowly, but did not disappear until $3000 \mathrm{~m}$. The peculiar conditions are probably partly caused by local influences, in particular by the mountain ranges of Madagascar ${ }^{\mathrm{E} 6}$.

Disturbance zones could almost always be found in the SE trade wind between 200 and $600 \mathrm{~m}$. They were either characterised by a change in the temperature profile or a decrease in relative humidity or by both, at times in combination with a change in wind direction. At $1400 \mathrm{~m}$, there was usually a second increase in temperature and a decrease in relative humidity, which previously had risen close to 100 per cent, to about 20 per cent. Further up, relative humidity usually remained very low, whereas the temperature decreased moderately quickly. At times, the lower layer disappeared in the course of the day. The wind conditions at these heights, described in the following, show that this is merely a disturbance zone caused by the surface. Only the second layer, starting between 1200 and $1400 \mathrm{~m}$, can be viewed as the boundary of the trade wind. For the monsoon winds, the layering was far less distinct than for the SE trade wind. The onset of the NE monsoon is noticeable in the upper layers at first, namely by sudden discontinuities in the vertical gradients of humidity, wind direction and velocity at the boundary of the lowest disturbance zone.
After having discussed the large-scale atmospheric circulation we turn back to the wind in the lowermost layers (mainly dealt with by Dr. ELIAS). For the layering of air currents the following picture emerged for the Lake Victoria between end of July and end of September:

1. Up to a few hundred meters, there were diurnal winds with a stronger development of the lake wind with regard to intensity and vertical extension.

2. Above that, up to about $3500 \mathrm{~m}$ a.s.l., there were weak winds with monsoon character with a diurnal pattern.

3. Above that, there was a seasonally modulated anti monsoon with a northerly component. Its upper limit fluctuates between 4120 and $8800 \mathrm{~m}$, the mean value is $6500 \mathrm{~m}$.

4. Above that, there were again almost exclusively easterly winds, mostly with a southerly component, but sometimes in certain layers also with a northerly component.

5. In the most elevated layers (mostly above $12000 \mathrm{~m}$ ), there were at times westerly winds. ${ }^{3}$

Below about $4000 \mathrm{~m}$, a rather complicated circulation system develops within the trade wind circulation. It results on the one hand from the land and lake winds,

\footnotetext{
${ }^{3}$ This very high westerly air flow that is currently still entirely puzzling has also been observed several times by VAN BEMMELEN and BRAAK over Batavia. ${ }^{\mathrm{E} 2}$
} 
and on the other hand from the flow towards the thunderstorm cumuli, which move from the land into the lake in the afternoon. The scheme in Figure 2 shows the details.

In the first morning hours a strong land breeze develops with an overlying onshore wind, which together strongly mix the air and generate an adiabatic lapse rate. Simultaneously, a second circulation system is introduced by the thunderstorm clouds that are over the lake in the early morning hours. The easterly air stream feeding the thunderstorm is strongest at about $900 \mathrm{~m}$ relative height where it is usually indicated by a disturbance of the vertical temperature profile. With increasing height wind speed decreases without a change of direction, above that - at about $3500 \mathrm{~m}$ - lies the return flow from the thunderstorm, and only between 3500 and $4000 \mathrm{~m}$ there is a pure trade wind. At 8 a.m. the land breeze already slows down, and between 10 and 11 a.m. a lake breeze starts, at first almost purely from $\mathrm{N}$, i.e., in a rather sharp angle to the coast, and later turning with the sun. The circulation system is much simpler now, because towards midday, strong cloud development takes place over the land so that the convergence centre [Aspirationszentrum] located here is strengthened by the lake breeze below. Two almost opposing air streams are now developed: a lower stream of $800 \mathrm{~m}$ thickness directed towards the land, above that a calm layer and further up a wind directed towards the lake. The onshore wind already ceases to blow at sunset; however, since the thunderstorm clouds have reached the coast in the meantime, the onset of the offshore wind is delayed until after 10 p.m. A consequence of the high-reaching diurnal wind change and accompanying mixing of the atmosphere up to $4000 \mathrm{~m}$ are the very small temperature differences from day to day and a very constant climate.

Along the coast, the sea and land winds reach a height of only 300 to $500 \mathrm{~m}$. During SW monsoon and SE-trade wind, they were much less distinct, partly due to the direction of the coastline (from SE to NW). In contrast to Lake Victoria, the sea breeze dominated with respect to duration, because it was reinforced by the flow towards the cumuli over the land, which lasted until late night. The daily winds were most regular during NE monsoon because this wind reaches the coast at Dar es Salaam almost perpendicularly.

In the appendix the regular daily course of the barometer at Lake Victoria is pointed out (recordings by a RICHARD-FUESS-Barograph ${ }^{\text {E14 }}$ between the end of July and end of September) because it clearly shows an 8-hour period with maxima at 2 a.m., 8 to 10 a.m. and 6 p.m. The equation of the daily course is:

$$
\Delta b=0.562 \sin \left(x-26.3^{\circ}\right)+0.828 \sin \left(2 x+140.9^{\circ}\right) .
$$

The variation during the entire day is very similar to Dar es Salaam (0.54); the constant of the second term is 0.95 when reduced to sea level. The third term, which is not calculated, is approximately $0.12 \sin 3 x$.

\section{Endnotes}

E1 BERSON, A., 1910: Bericht über die aerologische Expedition des Königlichen Aeronautischen Observatoriums nach Ostafrika im Jahre 1908. - Vieweg, Braunschweig, 119 pp.

E2 ARTHUR BERSON (1859-1942) was a German meteorologist and aeronaut. He was assistant of RICHARD ASSMANN at the Aeronautical Observatory of BerlinTegel and after 1905 at the Aeronautical Observatory of Lindenberg. BERSON left the position after returning from the expedition. See:

STEINHAGEN, H., 2009: Zum 150. Geburtstag von Arthur Berson. - dmg-Mitteilungen 04/2009, 11-13.

E3 Almost to thirds of the funding was provided by BERNHARD TEPELMANN, owner of Vieweg publisher in Braunschweig (STEINHAGEN, 2008). Vieweg later published BERSON's report and also was publisher of the Meteorologische Zeitschrift.

SteINHAGEN, H., 2008: Verlauf und Ergebnisse der Ostafrika Expedition 1908. - Presentation at BersonSymposium, Lindenberg, 12 Sep 2008.

E4 RICHARD ASSMANN (1845-1918) was a German meteorologist and physicist, discoverer (together with LOUIS TEISSERENC DE BORT) of the stratosphere in 1902. From 1905 to 1914 he was director of the Prussian Royal Aeronautical Observatory at Lindenberg. He is perhaps most widely known for the development of the aspiration psychrometer (EMEIS, 2012).

EMEIS, S., 2012: Assmann's development of aspiration psychrometers. - Meteorol. Z. 21, 431-435.

E5 HERMANN EliAs (1876-1955), German meteorologist and aeronaut. ELIAS had successfully collaborated with RICHARD ASSMANN and ARTHUR BERSON in previous aerological expeditions, see:

SteinHAGEN, H., 2009: Zum 150. Geburtstag von Arthur Berson. - dmg-Mitteilungen 04/2009, 11-13.

E6 Map showing the locations mentioned in this study (full black circles). Grey circles mark the positions from which the "MS Planet" performed aerological soundings (see E8).

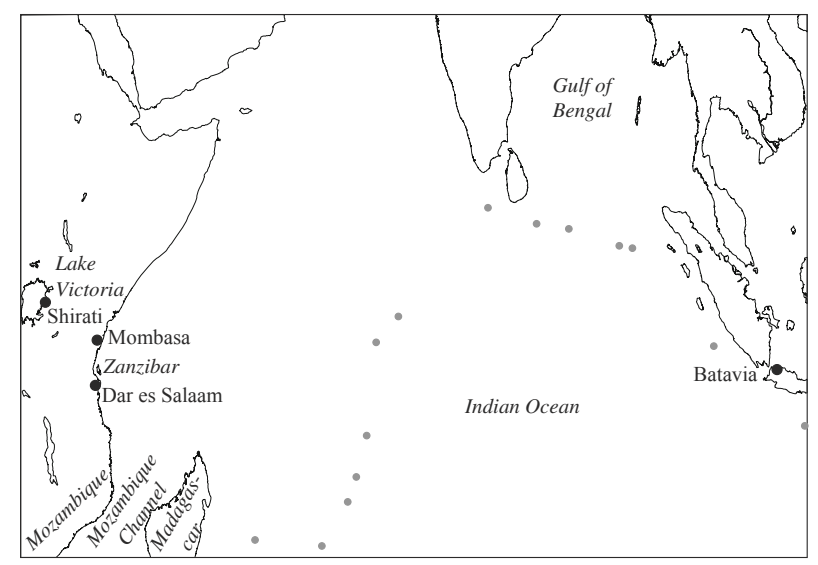

E7 FIELD, J. H., 1909: Drachenaufstiege in Indien. Meteorol. Z. 26, 417-418. 
E8 Brönnimann, S., G. P. COMPo, R. Spadin, R. ALLAN, W. ADAM, 2011: Early ship-based upper-air data and comparison with the Twentieth Century Reanalysis. - Clim. Past 7, 265-276.

E9 The table is not numbered and has no caption.

E10 The stratosphere, shortly after its discovery in 1902, was called „obere Inversion“" [upper inversion] (e.g., SCHMAUSS, 1909). The terms troposphere, stratosphere, and tropopause were only coined later. SCHMAUSS, A., 1909: Die obere Inversion. - Meteorol. Z. 26, 251-258.

E11 The table is not numbered and has no caption.
E12 VAn Bemmelen, W., C. BRAAK, 1910: Preliminary report upon the investigation of the upper air-layers begun at Batavia in 1909. - Verh. K. Akad. Van Wetensch. te Amsterdam [Proceedings of the Royal Netherlands Academy of Arts and Sciences, Amsterdam] 13 I, 149-157.

E13 The table is not numbered and has no caption.

E14 Rudolf HEINRICH LUDWIG FuEss (1838-1917), a manufacturer of meteorological and astronomical instruments, see also:

EMEIS, S., 2012: Assmann's development of aspiration psychrometers. - Meteorol. Z. 21, 431-435. 